\title{
Transformational Quest in Ray Bradbury's Fahrenheit 451
}

\section{David Pendery}

It was a pleasure to burn.

It was a special pleasure to see things eaten, to see things blackened and changed.

The opening words of Ray Bradbury's Fahrenheit 451 are at once eerie and bellicose, setting the tone for the chaotic, dystopian society that constitutes the narrative landscape of the novel, and hinting at the change that will color the novel. Indeed, from these opening lines, we can clearly see that transformation-psychic and societal —is the central theme and operative concept in the novel.

Much is happening in Fahrenheit 451, and the book can be viewed on several different levels. Bradbury has long been included in a "canon" of innovative science fiction writers from the 1940s through the 1960s, and when this label didn't quite fit (and it only occasionally fit), his work was variously included in the horror or fantasy genres. Though Bradbury certainly experimented in these different genres, none of them fully capture his style and themes, for he was always something of a conjurer, a blender of genres into a piebald body of work that almost defied classification. In all of his work, Bradbury borrows just enough of the conventions of particular genres to provide a measure of "regulation" and "order" to his work, but he is in the end a gleeful storyteller, energetically exploring psychological, philosophical and mythical themes in his sometimes wildly whimsical, sometimes authentically realistic tales. In short, Bradbury was rarely ever constrained by requirements of genre, requirements which have been bluntly labeled a type of "institutionalization" by Stephen Neal. ${ }^{1}$ In this sense, Fahrenheit 451 can be called "science fiction" only in a broad sense-but I concede that its science fictionality is essential, for it allows for the breadth of treatment of personal and social issues, and the expansive narrative landscape, in the novel. Science fiction had long allowed writers great freedom, flexibility, contingency and multidimensionality in their speculation. Even more important, by Bradbury's time, science fiction was moving from being a simply a genre on the fringes of the literary world, toward a much more didactic and active role in public consciousness, reinforcing expectations of personal and social change and development in the present and future. The creative freedom, multiple roles and focused agenda of science fiction permitted Bradbury to explore the issues he desired, while allowing for the genre-bending flexibility and narrative range he excelled in.

Emerging from the fertile ground of Bradbury's imagination, Fahrenheit 451 casts a bright light over the stultified 1950s American culture and politics. In the book, Bradbury formulates thoughtful criticism, makes perspicacious forecasts about American life and, most importantly portrays a disfigured, dystopian future. Social observation and critique are no doubt central to Fahrenheit 451, and most reviewers in the past have concentrated on the novel's social and political issues. ${ }^{2}$ However, I feel this is a limited view, and it should not surprise us that Bradbury had much more in mind when he wrote Fahrenheit 451. Indeed, our analysis and review will reveal that an overlooked element in the novel is its use of a quest structure as a frame for the narrative action and development, and as a vehicle for the exploration of social and personal transformation. The novel's protagonist, Montag, will undergo a quest not only to retrieve personal attributes he has lost (or simply lacks), but also to retrieve a lost Object for society and humanity-intellectual freedom, intellectuality and literacy. As noted, Bradbury is at heart a storyteller, exploring and illuminating human interaction and dilemma, and ingeniously utilizing the structures and devices of narrative. These skills he employs to excellent effect in Fahrenheit 451, for while we will see that a classic quest unfolds in the novel, Bradbury packaged the quest "in miniature," knowing that a more natural narrative feel and flow (as opposed to any idea of a "great" literary quest) would most appeal to his readers. Bradbury saw that America in the early 1950s needed a Hero to

${ }^{1}$ From The Study of Popular Fiction; A Source Book, Bob Ashley, Printer Publishers, London, 1989.

2 . The novel contains more than a few insightful predictions, not only of future technologies, but also of coming changes in American society. Bradbury foresaw (as well as anyone, really) the corrosive impact of mass media and shallow consumerism, of the "atomization" and alienation of steadily more narrowly defined social groups making ever more dogmatic demands on society (Bradbury's description of this includes an amusing depiction of what would one day be called "political correctness"), and the advent of "Age of Aquarius" idealism and anti-war sentiments in the 1960s. 
stand up to looming ignorance, to retrieve and return a valued Object the society was losing. But he knew that such a hero would not be an "epic hero," but rather, an "everyman" of his time, courageous but empathetic, embodying the unique American combination of a sometimes-provincial outlook, and universal political and social ideas.

The body of this paper will be divided into two sections. In Section I, which is divided into three parts, our evaluations and descriptions stem from a "close reading" of the novel's text. In Section I parts 1 and 2, I will examine two principal themes in Fahrenheit 451-culture and transformation. In part 3 I shall examine a sampling of Bradbury's use of language in the novel. Bradbury's language is famously lyrical, and his writing exhibits a "mystery and connotative depth" far superior to most other science fiction writers of his age. ${ }^{3}$ Our examinations in Section I will be somewhat selective, and they are intended primarily as background to complement the structural analysis in Section II.

Because it is "impossible to [to produce] a narrative without reference to an implicit system of units and rules," 4 Section II will employ a "building block" narratological/structural approach to analyze and describe essential plot elements in Fahrenheit 451. Basing our analysis on the work of Lithuanian/French semiotician A.J. Greimas and Russian critic and theorist Vladimir Propp, I hope to not only further illuminate Fahrenheit 451's concepts of social and personal transformation, but also to expose the quest embedded in the social critique and "science fiction" of the novel. Section II is divided into two parts. In part 1, I will organize and analyze character and plot elements of Fahrenheit 451 based Greimas's "opposition" taxonomy of narratives. This analysis will reveal a "structural coding" made up of binary characterizations, which highlight the social and psychological themes in the text. In Section II Part 2, I shall loosely base our analysis on Propp's description of the "functional" attributes of narrative. I shall propose a Transformational Quest Plot Schemata for Fahrenheit 451, which will expose a uniform series of narrative utterances in the text. I feel that Greimas's and Propp's work complement each other extremely well, and can even be viewed as two sides of the same coin, as it were. Our description based on Greimas's work can be viewed as a "horizontal" description of characterization, motives, and objectives, while our Proppian analysis can be seen as a "vertical" description of Fahrenheit 451's plot and action. I beg the reader's indulgence, as I will ultimately fold Greimas's terminology (with our own additions) into our Proppian schemata.

Following Section II, I shall provide brief concluding comments.

\section{Section I}

\section{Culture and Society}

Ray Bradbury surveyed American society in 1953, and did not like what he saw. Ham-fisted political conservatism and chilly puritanical cultural values were in ascendance. The Cold War was taking shape, hot war had flared on the Korean peninsula, and something like the threat of "permanent war" seemed to loom ominously over the United States (and the rest of the world). In American politics, Joseph McCarthy had launched his Communist witch-hunts, which would blight American culture and politics for decades. American society seemed ripe for transformation, badly in need of a purging to rid it of sociocultural rot that had festered for decades. True, the nation was blessed with rapidly expanding wealth and middle-class comfort, but even this was giving rise to a vapid, materialist consumer culture. The nation seemed on the verge of taking a reactionary, anti-intellectual, isolated path inimical to its own literate ideals. Bradbury focused his authorial lens on this culture, using the backward "culture of book burning" (a twisted sort of "transformation" endorsed by the likes of McCarthy and many others in the 1950s in the United States) as his principal image and motor of the narrative in Fahrenheit 451.

It is important to clarify the causes and effects at work in this morass. ${ }^{5}$ And morass Bradbury's envisioned society is—a people engulfed in endless trivial pursuits including "organized super-super-sports," "Fun Parks," "Car Wreckers," "acrobats, magicians, daredevils, jet cars, motorcycle helicopters, sex and heroin," "three-dimensional sex magazines," wall-sized virtual reality television shows perpetually broadcasting yammering "family members" and tissue-thin romances, and gangs of these mindless creatures roaring around the cities and countryside in their cars at $130 \mathrm{mph}$, targeting animals and sometimes people (hardly a trivial pursuit, that). ${ }^{6}$ One character in the novel tells protagonist Guy Montag that his quest to re-enlighten this society

\footnotetext{
${ }^{3}$ Readings on Fahrenheit 451, Literary Companion Series, Greenhaven Press, 2000.

${ }^{4}$ Roland Barthes, "Introduction to the Structural Analysis of Narratives," from Image-Music-Text, 1977, by Roland Barthes. This quotation taken from A Roland Barthes Reader, ed. Susan Sontag, Vintage, 1989.

5 Presumably the novel is set in the United States, but Bradbury's only identification of the locale is a brief reference to the

American Civil War as he describes the historical roots of current social conditions.

6 Ray Bradbury, "Fahrenheit 451, Random House Publishing Group, 1953, p. 57-61.
} 
is futile, because "people are having fun." Another reminds Montag "if the drama is bad, if the film says nothing, if the play is hollow...I don't care. I just like solid entertainment." " Needless to say, books, reading and literacy are not high on citizens of this society's list of preferred activities. I shall examine Bradbury's unique explanation of the causes and effects that resulted in Fahrenheit 451's deformed society, but let us first review the society's background and constitution.

We learn that technological advances instigated the social transformation (the step backward, we might say), as the pace of life increased, and mass media began to churn out "condensations, digests, tabloids," "classics cut to fifteen-minute radio shows," and news that was a thin gruel of "one column, two sentences, a headline!" In the end, life became ever more "immediate" ("Wallop, Bing, Bong, Boom!" enthuses Fire Chief Beatty, the novel's chief antagonist, as he mockingly describes the roots of the social decay to Montag ${ }^{10}$ ). and the only reading material the public wanted were how-to manuals, trade journals, confessions, and the above-mentioned 3D sex magazines.

During this era of advancing technology (roughly described as beginning in the late Industrial Revolution and proceeding to the undated future of the novel), the population grew exponentially. Once, "the world was roomy," and people "could afford to be different"11 (by indulging in ideas in books). However as the population grew, and masses of people sought more and more of the leisurely asides that were being provided in this consumer-society-on-steroids, "books [were] leveled down to a sort of pastepudding norm." 12 As the population grew, society fragmented into a mass of competing groups (called "minorities" by Bradbury, but not meant in the traditional sense of underrepresented groups outside the Caucasian majority in the United States, and meaning instead any "special interest" group, e.g. "dog lovers, cat lovers, doctors, lawyers, merchants, chiefs, Mormons, Baptists, Unitarians, second-generation Chinese, Swedes, Italians, Germans, Texans..."13). These groups demanded equality with other groups, and cultivated the "politically correct" conformist environment referred to in the introduction to this paper, in order to protect themselves from criticism and perceived hurts.

This background sets the stage for one of Fahrenheit 451's most interesting narrative twists, for one would expect that an authoritarian government would be the source of this oppression - torching books to pacify a populace, limit expression, and take control of the reins of history, a la Orwell's 1984. But this is not the case in Fahrenheit 451. "There was no dictum, no declaration, no censorship," proclaims Beatty. "Technology, mass exploitation, and minority pressure carried the trick...." ${ }^{14} \mathrm{He}$ continues that books are not an enemy for the knowledge they provide, per se, but for the uncertainty, complexity and unhappiness they would introduce into a society that craves conformity and reduction to the easiest, most practical common denominator. The government in this society reinforces (not "enforces") the social decay by burning books. But it was not, primarily (or originally), the government that engineered these conditions. Rather, books in the world of Fahrenheit 451 have for the most part willingly been abandoned by people. All of the people in the society in Fahrenheit 451 desperately need conformity. Individuals want the certainty of conformity to provide yet more unthinking "warm bodies" to participate in the culture of play that infuses this society ("Don't give them philosophy, that way lies melancholy," 15 advises Beatty). Groups (minorities), meanwhile want conformity for the protection it provides them. The public "stopped reading of its own accord" explains Faber, Montag's principal helper in the book. ${ }^{16}$ In short, for all their importance, it was not the disappearance and destruction of books that tore society apart, but the torn society that rejected books.

Comparing Fahrenheit 451 with Orwell's 1984 is always tempting. Both novels were published in (roughly) similar social and political contexts, and they contain parallels of psychological and social alienation, intellectual decay, and dangerous political and social climates where books and ideas are banned, burned or rewritten. However, the parallels are limited, and we can see the very different personal, social and political issues that the two authors experienced and ultimately addressed. World War II and the rise of the Cold War were no doubt at the forefront of both writer's perceptions, but Orwell was much more attuned to and nearer the threat of full-scale totalitarian repression. England had only a few years before lived (and to some extent still was

\footnotetext{
7 Bradbury, ibid, 87.

${ }^{8}$ Bradbury, ibid, 61.

${ }^{9}$ Bradbury, ibid, 54 .

${ }^{10}$ Bradbury, ibid, 55.

${ }^{11}$ Bradbury, ibid, 54.

${ }^{12}$ Bradbury, ibid, 54.

${ }^{13}$ Bradbury, ibid, 57.

${ }^{14}$ Bradbury, ibid, 58.

${ }^{15}$ Bradbury, ibid, 61.

${ }^{16}$ Bradbury, ibid, 87.
} 
living) in a wartime environment of suppression and government control of information, with all of the attendant distortions of reality, propaganda and rank nationalism-cum-autocracy. England was also much more attuned to the reality of communism (communism was in a sense originated in England, and both the U.K. and Russia were part of a greater European polity and culture that embraced communism and socialism far more readily than the United States), which of course the politically astute Orwell was entirely disillusioned with. The ruins of Europe and an already-belligerent USSR at his doorstep, Orwell was not in a playful mood when he wrote the harshly pessimistic 1984. Bradbury, meanwhile, lived in a nation that had seen nothing like the destruction that England and Europe had in WW II, and by 1950 when he began Fahrenheit 451, the United States had all but left the pain of war behind, and was on the threshold of an economic miracle that would give rise to an insipid materialism that was the exact opposite of the destitution and destruction that still afflicted much of Europe. The only control of information in the U.S. that concerned Bradbury, meanwhile, was that of a puritanical right wing that was in ascendance (whose book and recordburnings in junior high schools were alarming, but anything but the overarching threat to human freedom that Orwell visualized), and of the major television networks, which were feeding the first spoonfuls of a diet of "pastepudding" entertainment to the U.S. public.

Orwell's view has long dominated society's perception political control and intellectual suppression (and no doubt his view was even more influential in the immediate years after 1984's publication in 1948), and so Bradbury's portrayal of the roots of the problems that plague future society turns expectations about cause and effect in dystopian worlds around. By doing this, he cast a hard light of criticism on cultural values and behavior, and the threat of rot from within, rather than the more standard notion of an aggressive authoritarian government controlling information and suppressing freedom from without. Yes, the government is a danger, but a misguided and debased "people power" is the real scourge that brought about the social decay in Fahrenheit $451 .{ }^{17}$ In response, Bradbury sets into motion processes of transformation, beginning with the transformation of Guy Montag, who changes from a ignorant and docile "fireman" (note there are no "firefighters" in Bradbury's future, only "firemen") to a courageous rebel intent on transforming society.

\section{Transformation}

Although Fahrenheit 451 employs or examines a range of psychological ideas and concepts - human happiness and depression, conformity and rebellion, alienation and disillusionment, creative/destructive poles in relationships, and betrayal-I shall specifically examine transformation as a unifying theme in the novel. This transformation is writ "small" in the personal development of protagonist Guy Montag, and "large" in the society he lives in. Transformation is also a key concept in any quest narrative, which will be examined in more detail in Section II of this paper.

At the personal level, we witness Montag's transformation from an unthinking automaton-a lonely and purposeless man-into an intellectually independent, reflective and courageous human being. Bradbury sets the wheels of transformation turning almost immediately in the novel, with the famous first lines of the book:

It was a pleasure to burn.

It was a special pleasure to see things eaten, to see things blackened and changed.

The words simultaneously indicate Montag's smug confidence in his position, as well as forecasting his coming transformation ("to see things...changed"). We initially see Montag as a villain-a brutish book-burner who is every bit as obsessed with the destruction of knowledge as others that live in the society. But we soon learn that he is not as smugly confident as he initially boasts. We see in fact that he is unsettled and ripe for transformation, as he gloomily realizes that "I'm not happy, I'm not happy," 18 and later anxiously wonders, "How do you get so empty?... Who takes it out of you? ${ }^{19}$ Montag's transformation is prompted by Clarisse, his waif-like 17-year-old next-door neighbor, whose searching questions trigger Montag's selfexamination. ${ }^{20}$ After meeting her, his head is soon spinning with confusing thoughts. "How like a mirror, too, her face. Impossible; for how many people did you now who refracted your own light to you?" Through Clarisse, Montag is first able to sense his own doubts, and his head is soon spinning with the thought, "I don't know anything any more..." 21 and he feels his

\footnotetext{
${ }^{17}$ Some might accuse Bradbury of being an "elitist," rejecting the "people's choice."

${ }^{18}$ Bradbury, ibid, p. 65.

${ }^{19}$ Bradbury, ibid, p. 44.

${ }^{20}$ Clarisse represents Bradbury's forecast of the ascendance of youthful idealism and anti-war convictions in American society in the 1960s, although Montag independently embraces this belief throughout the novel.

${ }^{21}$ Bradbury, ibid, p. 18.
} 
body "divide itself into a hotness and a coldness, a softness and hardness, a trembling and a not trembling, the two halves grinding one upon the other." 22 Montag's "divided self" will appear again in other parts of the narrative.

At this point, Montag's transformation is only incipient. The remainder of the book portrays a steady "firming up" of his change, as he confronts his own failings, rebels against the societal values he now detests, and begins his quest to retrieve what has been lost in himself (“...I think it's so strange you're a fireman. It just doesn't seem right for you, somehow" ${ }^{23}$ ) as well as lost to society ("Lord, there were a lot of lovely pages once, before we let them go" 24 ). His transformation is nearing completion when he is on his way to his last day of work at the firehouse, the day he will murder Beatty, and begin his final quest for absolution by joining the 'forest people' and their mission for societal renewal:

His mind would well over at last and he would not be Montag any more, this the old man told him, assured him, promised him. He would be Montag plus Faber, fire plus water, and then, one day, after everything had mixed and simmered and worked away in silence, there would be neither fire not water, but wine. Out of two separate and opposite things, a third. A going away from the self he had been. ${ }^{25}$

Montag is now ready to implement his own violent transformation of society-but his plan will never unfold. His own transformation proceeds apace, however, and as he sets out to find the book-loving 'forest people' who will be his instrumental helpers in his quest, he finds himself transforming from a destructive into what might be termed a generative self. In the novel Montag is continually consumed by the flames of his existence (his destructive job, his collapsing marriage, his fractured society), and his personal quest is to quench these flames, to rediscover and reconstitute himself in a constructive way. As he lazily floats toward his meeting with the "forest people' he finds that he will "never burn again in his life."26

Montag's plan to destroy the existing order is vetoed by the "forest people," and in any case never gets a chance to be instigated, for in the climax the hint of war in the background throughout the novel explodes in a nuclear holocaust. In this firestorm, the societal purging takes place, but the last element of Montag's own transformation is not yet secure. There is one last memory he must retrieve to find peace: he must recall where he met his wife. Earlier in the novel he had asked his wife, and she had responded:

"When did we meet? And where?"

"When did we meet for what? she asked. ${ }^{27}$

At the novel's climax, with Montag prostate on the ground outside of the city as the bomb blasts roar, he recalls: "I remember.... I remember.... Chicago a long time ago. Millie and I. That's where we met! I remember now. Chicago. A long time ago. ${ }^{28}$ With this retrieval of memory, Montag's personal transformation is now complete. Society, meanwhile, lies in ashes, and it is now for Montag and the 'forest people' to return to the shattered society to complete the grater constructive transformation by "remembering." 29

\section{Language}

The following examination of Bradbury's use of poetic language in Fahrenheit 451 is not a technical analysis. Rather, I will examine the aesthetic elements of Bradbury's language, looking at its color, texture and inventiveness. Bradbury has himself said he possesses that most basic quality of a joyful writer: he loves words and ideas. The narrative structure and technique in Fahrenheit 451 are not, on their surface, deeply innovative. For the most part, the story is told "straight," with Bradbury giving the characters a "podium" (as he has said) from which they can tell the tale. Writing for Bradbury, however, is always more than

\footnotetext{
${ }^{22}$ Bradbury, ibid, p. 24.

${ }^{23}$ Bradbury, ibid, p 24.

${ }^{24}$ Bradbury, ibid, p 81.

${ }^{25}$ Bradbury, ibid, p 103.

${ }^{26}$ Bradbury, ibid, p 141.

${ }^{27}$ Bradbury, ibid, pp 42-43.

${ }^{28}$ Bradbury, ibid, p. 160.

${ }^{29}$ Bradbury, ibid, p. 141. We have modified Bradbury's word, but not his meaning.
} 
the sum of its narrative parts, and it is, rather, a "celebration." ${ }^{30}$ Bradbury fashions a highly multidimensional narrative in Fahrenheit 451, combining standard narrative revelation, poetry, a great deal of dialog to reveal action, something very close to "stream-of-consciousness" internal dialogs, references to classic western literature, and modernistic techniques such as the use of lists and montage. (This description might seem to conflict with our contention that Fahrenheit 451 is not innovative, but the actual plot traverses a straightforward path from beginning to end.) Bradbury always reveled in the "texture" of language, the "pores" of its complexion, and this results in many beautiful phrases and images in the novel. Consider for example, this lovely poetic passage, as Montag meditates on time and transformation as he floats in the river after escaping his pursuers:

And what lights the sun? It's own fire. And the sun goes on, day after day, burning and burning. The sun and time. The sun and time and burning. Burning.... Burning. The sun and every clock on the earth. It all came together and became a single thing.... The sun burnt every day. It burnt Time. The world rushed in a circle and turned on its axis and time was busy burning the years and people anyway, without any help from him. So if he burnt things with the firemen and the sun burnt Time, that meant that everything burnt! ${ }^{31}$

Or the following example, which is similar in that it employs a time theme and similar language, but with its more optimistic tone also contrasts with the foregoing passage:

She had a very thin face like the dial of a small clock seen faintly in a dark room in the middle of a night when you waken to see the time and see the clock telling you the hour and the minute and the second, with a white silence and a glowing, all certainty and knowing what it had to tell of the night passing swiftly on toward further darknesses, but moving also toward a new sun. ${ }^{32}$

In addition to lyrical passages such as these, Bradbury employs an innovative literary technique in his use of lists and associative montages in Fahrenheit 45 (a technique used frequently by J.G. Ballard, who wrote of the hypnotic power of seemingly random lists, which disrupt normal exposition, and force readers to focus on associations.) Sometimes these lists are used pragmatically, to condense information and provide urgency to what a character is describing. An example spoken by Beatty reads:

With school turning out more runners, jumpers, racers, tinkerers, grabbers, snatchers, fliers, and swimmers instead of examiners, critics, knowers and imaginative creators... ${ }^{33}$

More interestingly, these lists are frequently in the form of stream-of-consciousness internal dialogs in the character's minds. The following example rushes through Montag's mind as he ponders the unsettling events of meeting Clarisse, and then finding that his wife had attempted suicide:

One drop of rain. Clarisse. Another drop. Mildred. A third. The uncle. A fourth. The fire tonight. One, Clarisse. Two, Mildred. Three, uncle. Four, fire. One, Mildred, two, Clarisse. One, two, three, four, five, Clarisse, Mildred, uncle, fire, sleeping tablets, men disposable tissue, coattails, blow, wad, flush, Clarisse, Mildred, uncle, fire, tablets, tissues, blow, wad, flush. One, two, three, one two, three! Rain. The storm. The uncle laughing. Thunder falling downstairs. The whole world pouring down. The fire gushing up in a volcano. All rushing on down around in a spouting roar and rivering stream toward morning. ${ }^{34}$

"One drop of rain. Clarisse. Another drop. Mildred. A third. The uncle. A fourth. The fire tonight;" "Rain. The storm. The uncle laughing. Thunder falling downstairs...All rushing on down around in a spouting roar and rivering stream toward morning." Delightfully creative and animated language from Bradbury!

${ }^{30}$ Bradbury, ibid, p. 189.

${ }^{31}$ Bradbury, ibid, p. 141

${ }^{32}$ Bradbury, ibid, p. 10.

${ }^{33}$ Bradbury, ibid, p. 58.

${ }^{34}$ Bradbury, ibid, pp. 17-18. 
Another example of this technique is the classic verbal fusillade from Beatty, as he peppers Montag with a dizzying explanation of how their society has reached its current debased condition. The use of italics and nonsense words gives the passage a slapstick quality:

"Speed up the film, Montag, quick. Click, Pic, Look, Eye, Now, Flick, Here, There, Swift, Pace, Up, Down, In, Out, Why, How, Who, What, Where, Eh? Uh! Bang! Smack! Wallop, Bing, Bong, Boom!

Bradbury takes his experimentation with language in another spirited direction with his energetic use of exclamation points throughout the narrative, which not only emphasize various passages, but also take the text into areas of mischievous wordplay:

- If we have to burn, let's take a few more with us. Here!

- He shouted to give himself the necessary push away from this last house window, and the fascinating seance going on in there. Hell! and he was away and gone!

- The night looking at him. The forest seeing him. The Hound!

- The salamander devours his tail! Ho! God! $!^{35}$

As a final note, it is interesting to view Bradbury's attention to detail and meaning, right down to the names he selected for the main characters in Fahrenheit 451:

- Guy Montag: Originally means "man" or "person," and has also come to be a generic, unisexual reference to a person, indicating Montag's "everyman" status. Montag is also German for "Monday," denoting Montag's role as a "beginning."

- Beatty: Originally means "bringer of joy," which is darkly ironic given Beatty's role in the novel.

- Faber: Originally means "bean grower," indicating Faber's role as a "planter" of ideas, or "cultivator" of Montag's quest to save society.

- Clarisse: Originally means "clear, bright," the meaning of which is apparent in the context of the novel.

- Mildred: Originally means "mild of strength," indicating Mildred's intellectual and personal weakness. The name, even in Bradbury's time, was almost archaic in the United States, and considered a somewhat dowdy name for women. Bradbury's choice highlights Mildred's personal drabness.

Bradbury's language and imagery in Fahrenheit 451 are more than attempts to assemble narrative meaning-they are celebrations. In the various examples I have examined, it can be seen that Bradbury is a master of language, a poet of sorts, a "writer's writer." As in all of his work, he brings a multi-textured approach to his writing in Fahrenheit 451, skillfully weaving reflection, lyrical passages, poetry, fun-filled wordplay, standard narrative revelation, and other innovative techniques into his language tapestry.

\section{Section $\mathbf{I I}^{36}$}

\section{Fahrenheit 451 Opposition Matrix Plot Description, based on A.J. Greimas}

I shall now attempt to "plot the plot" and narrative flow of Fahrenheit 451, based on the work of A.J. Greimas (Section II part 1) and Vladimir Propp (Section II part 2). Our focus on plot in these sections is not incidental. Plot, needless to say, comprises the characters, locales, motives and action that constitute "the plan or main story of a literary work." I would like to direct the reader's attention to an important attribute in this definition, an attribute which, interestingly, is common to all definitions of plot - whether a narrative discourse, a ground plan, a secret plan, or a graphic representation (as a chart). ${ }^{37}$ This is the element of design, which is essential to any understanding of the plot of fictional narrative. Writers design plots, and plots are thus best fully understood as designs rather than simply "stories." By exposing elemental design, we can more clearly see many core elements of narratives that might otherwise be opaque beneath any number of other creative, analytical or descriptive elements and layers

\footnotetext{
${ }^{35}$ Bradbury, ibid, pp. 122, 138, 144, 86.

${ }^{36}$ For many helpful suggestions during development of Section II of this paper, I am indebted to attendees of the graduate seminar "American Popular Fiction: Oral Tradition and Narrative Theory," led by Professor Chao-ming Chen, National Chengchi University, Taipei, fall 2003.

${ }^{37}$ Definitions based on Merriam-Webster's Collegiate Dictionary, Tenth Edition, 1998.
} 
of information fixed in narrative discourse. As I have repeatedly noted, Bradbury is first and foremost a storyteller, and often a grand storyteller, and the decades-long focus on Fahrenheit 451's social themes has missed important elements of Bradbury's plot. Also noted, I believe that A. J. Greimas's "oppositions" and Propp's "functions" are highly complementary, and in combination will highlight fundamental axes in Fahrenheit 451's quest-its oppositions and consequent confrontations, characters and roles, motivations and aims. Of course the hero of this quest is Montag, the novel's protagonist, and his own transformation, as well as that of the decayed society he lives in (and several incidental characters in the novel) are essential outcomes of his quest.

In the Section II Part 1, I present a tabular (or matrix) plot description, based on A.J. Greimas's work describing opposing forces (called actants or actantial roles by Greimas) and instrumental characters (called actors by Greimas) in narratives. I have furnished the plot elements of Fahrenheit 451 that correspond to Greimas's terms (names of actors and descriptions of actants) and created additional terms and characters to be used in tandem with Greimas's. I agree that Greimas's subject-object opposition taxonomy "characteristically generates stories of quests," ${ }^{38}$ and applying Greimas's analysis to Bradbury's novel effectively highlights the quest structure and characters in Fahrenheit 451. This binary opposition is fundamental to Greimas's analysis, and also fits well with the transformational quest theme in Fahrenheit 451. Quests are nothing if not representations of "fundamental actions of disjunction and conjunction, separation and union, struggle and reconciliation..." 39 among opposing forces, with the pursuit of, attainment, and transfer of an essential object to a receiver. It is just this dynamism that I attempt to illustrate, by adding an element of verbal action and movement - the quest in Fahrenheit 451 - to Greimas's diagram. This addition of a verb logically links the subject and object (Montag and a literate society, respectively) in Greimas's "grammar," yielding a complete performative structure of subject, verb, object/trial, struggle, task - essential elements in narrative generally, and in quests specifically. I make no attempt to change Greimas's intent or design, and only try to clarify or bolster his structure (if I may be so bold). Greimas's terms and design, I feel, are essentially self-explanatory - a clear organization of binary oppositions and stabilizing central elements that describe the origins of the narrative tension, characterization, and overall action of a narrative. Bradbury's employment of these elements in his transformational quest narrative propels his examination and critique of American culture.

Below find the Greimas diagram, completed as I have described (the addition of the verbal quest, highlighted in yellow, is the principle change I have added). Following the diagram is a series of textual examples from Fahrenheit 451, accompanied by important notes, explanations and further analysis, to deepen and extend our description of the quest in Fahrenheit 451 (particular attention is paid to the Subject section, which includes further analysis of transformation in the novel). I will complete this narratological/structural analysis and description in Part 2 of Section II, by combining Greimas's and our terms with theory and terms innovated by Vladimir Propp.

\section{Fahrenheit 451: Opposition Matrix Plot Description}

\begin{tabular}{|c|c|c|c|}
\hline $\begin{array}{c}\text { Sender (Provider): } \\
\text { Literate society }\end{array}$ & $\begin{array}{c}\text { Object: } \\
\text { Intellectual freedom, } \\
\text { intellectuality and titeracy } \\
\text { as essential elements of } \\
\text { culture and society }\end{array}$ & (Quest) & $\begin{array}{c}\text { Receiver: } \\
\text { Humanity/society }\end{array}$ \\
\hline & (Quêt) & & \\
\hline $\begin{array}{c}\text { Helpers: } \\
\text { Change Agent, (Clarisse); } \\
\text { Principal Helper (Faber); } \\
\text { Instrumental Helpers } \\
\text { ('forest people') }\end{array}$ & Subject: Montag & & $\begin{array}{c}\text { Opposition: } \\
\text { Beatty; the } \\
\text { Mechanical Hound } \\
\text { (preserver of } \\
\text { principles); the } \\
\text { degraded } \\
\text { society/citizens }\end{array}$ \\
\hline
\end{tabular}

\footnotetext{
${ }^{38}$ Terrence Hawkes, Structuralism and Semiotics, Routledge, London, 1997, p. 92.
}

${ }^{39}$ Hawkes, ibid, p. 90. 


\section{Illustrations and examples of the primary terms, roles and action from the text of Fahrenheit 451, based on the Greimas diagram (with author's additions)}

\section{Sender/provider}

I add the term "provider" because I feel Greimas's term "sender" is a bit too anthropocentric. In our analysis, the object is not only sent but also a quality or agent that is available a sort of providence for humanity or society. In the case of Fahrenheit 451, it is true that a literate society is the sender of the object, but only abstractly, for such a society is not in existence, or is in serious decay, at the time of the action in Fahrenheit 451. In any case, the object ("intellectual freedom, intellectuality and literacy as essential elements of culture and society") is more than simply "sent" toward the hero and the receiver, it is also a providence, a quality controlled by no agent and available to all, as a sort of godsend or grubstake. This "higher" view is in keeping with Bradbury's somewhat conservative view, amply expressed in the novel, of where literacy and intellect truly resides: in a classic canon of western authors and works that includes no less than Faulkner, Whitman, Dr, Johnson, Alexander Pope, Shakespeare, the Bible, etc. In any case, his point about intellectual freedom, intellectuality and literacy (whatever the roots of those may be) as pillars of dying culture is abundantly clear. This object is at once refused, denied, lost, ignored or valued in Fahrenheit 45, but it is sent only in a broad sense. It is, at heart, a providence available but currently lost.

- "Do you know why the books are so important? Because they have quality. And what does the world quality mean? To me it means texture. This book has pores. It has features. This book can go under the microscope. You'd find life under the glass, streaming past in infinite profusion."

- "The things you're looking for... are in the world, but the only way the average chap will ever see ninety-nine percent of them is in a book." ${ }^{40}$

\section{Object}

The definition and role of the Object, as the primary objective of the Subject's quest in the novel is, I believe, straightforward.

- "Would books help us?"

"Only if the third necessary thing could be given us.... The right to carry out actions based on what we learn from the interaction of [quality of information and the leisure to digest it].

- "You're afraid of making mistakes. Don't be. Mistakes can be profited by. ${ }^{41}$

\section{Transformative Quest}

This concept encompasses the Subject's pursuit of the Object, his journey to provide the Object to the Receiver, and the subject's transformation. The transformative quest is discussed in more detail below, in "Subject."

- In the days to follow, and in the nights when there was no moon and in the nights where there was a very bright moon shining on the earth, the old man would go on with this talking and this talking, drop by drop, stone by stone, flake by flake.... And one day he would look back upon the fool and know the fool. Even now he could feel the start of the long journey, the leave-taking, the going-away from the self he had been. ${ }^{42}$

\section{Receiver}

Note the use of the personal pronouns "we" and "us" in the following examples, exemplifying community and society (the ultimate Receiver) in the statements.

- "The magic is only in what books say, how they stitched the patches of the universe together into one garment for us."

- "The books are to remind us of what asses and fools we are. They're Caesar's praetorian guard..."

\footnotetext{
${ }^{40}$ Bradbury, ibid, pp. 83, 86 .

${ }^{41}$ Bradbury, ibid, p. 85, 104.

${ }^{42}$ Bradbury, ibid, pp. 102-103.
} 
- 'So, Montag, there's this unemployed printer. We might start a few books, and wait on the war to break the pattern and give us the push we need."43

\section{Helpers}

The fact that Fahrenheit 451 has Helpers sprinkled throughout the narrative is indicative of the narrative's quest, as any lengthy quest will typically require a series of Helpers, aiding the Subject as he or she encounters a variety of opponents, adversaries, challenges, etc. Therefore, I have identified three Helpers, of increasing importance (or in any case with different roles), at different stages of the narrative in Fahrenheit 451. The terms I use, I feel, are essentially easy to understand. Clarisse, as the Change Agent, prompts the Subject's initial transformation, his questioning of received wisdom and his own ingrained values. Faber, as the Principal Helper, provides the first serious aid to Montag during his question. The "forest people," as Instrumental Helpers, are the most important helpers, not only assisting Montag during his quest and for practical reasons, but also joining him in his ultimate aim to provide the Object to the Receiver.

\section{Change Agent (Clarisse)}

- Of course I'm happy. What does she [Clarisse] think? I'm not?

- He glanced back at the wall. How like a mirror, too, her [Clarisse's] face. Impossible; for how many people did you now who refracted your own light to you?... How rarely did other people's faces take of you and throw back to you your own expression, your own innermost trembling thought? ${ }^{44}$

\section{Principal Helper (Faber)}

- "What do you want?"

"I need you to teach me."

"All right, all right."

- "Montag!"

The voice was in Montag's head.

"I hear you!"

... "You're coming over fine, too!" Faber whispered but the voice in Montag's head was clear. "Go to the firehouse when it's time. I'll be with you." 45

\section{Instrumental Helpers ('forest people')}

- "All right, you can come out now!" Montag stepped back in the shadows.

"It's all right," the voice said. "You're welcome here."

- The other men helped, and Montag helped, and there, in the wilderness, the men all moved their hands, putting out the fire together.

- "We'll have a bite. Then we'll turn around and walk upstream. They'll be needing us that way." 46

\section{Subject/Transformation}

Transformation, a key concept in any quest narrative, is central to Fahrenheit 451. Montag's transformation on two levels-his personal transformation from ignorance into self-realization, and his higher-level transformation from Villain into Hero-is ongoing throughout the novel, Below I present examples illustrating both characterizations. Additional elements of Montag's Heroic transformation will be examined in Section II, Part 2 of this paper.

Although Montag's personal and heroic transformation is a central thrust of the narrative, transformation also takes place on several other levels in Fahrenheit 451. For example, the roles of Helpers and Opposition, so clearly delineated throughout the novel (in Clarisse, Beatty, etc.), are reversed at the beginning of the novel. This must quickly be inferred by readers, as they

${ }^{43}$ Bradbury, ibid, pp. 83, 86, 89 .

${ }^{44}$ Bradbury, ibid, pp. 4, 10.

${ }^{45}$ Bradbury, ibid, pp. 88, 91 .

${ }^{46}$ Bradbury, ibid, pp. 146-147, 154, 163. 
realize that because Montag is a Villain in the first pages of the novel, those who will later be his Helpers are his opposition at that time, and those who will later be his Opposition are his Helpers! Although these characters are not themselves internally transformed, their roles in the novel are. These "lower tier" transformations, while not prominent in the overall narrative structure of Fahrenheit 451, are important catalyzing forces, and also strengthen the overall theme of transformation in the novel. The transformation of the actantial roles of the Helpers and Opposition in Fahrenheit 451 illustrates a concept described by Greimas: that of the single actor evincing more than one actant. Other actants in the narrative are not so clear, however. For example Montag's wife Mildred is used in a similar twofold way, but without experiencing any particular transformation. Although she nominally plays both roles of Opposition and Helper in the text, she is never quite fully realized as either. Similarly, but more broadly, the society at large in Fahrenheit 451 plays an ambiguous role. The society is for most of the narrative portrayed as a fairly villainous presence - a vapid, anti-intellectual place, bent on self-degradation, essentially one with the Opposition in the novel. However, it is this very society that Montag, with his Helpers, is intent on changing for the better. Thus, the society is never truly viewed as Opposition by Montag, and his aim continues to be to deliver to it the salutary Object: intellectual freedom, intellectuality and literacy as essential elements of culture and society.

A single instance of Montag's personal transformation is provided below, but other transformative signals (of the lesser actors, society, etc.) are not included. Note also that transformation is not included as a formal element in the plot diagram above, though logically it occurs during the text's quest.

\section{Villain}

- It was a pleasure to burn.

It was a special pleasure to see things eaten, to see things blackened and changed.

- "It's fine work. Monday burn Millay, Wednesday Whitman, Friday Faulkner, burn 'em to ashes, then burn the ashes. That's our official slogan." 47

\section{Hero}

- Montag only said, "We never burned right."... and then [Beatty] was a shrieking blaze, a jumping, sprawling gibbering mannikin, no longer human or known, all writhing flame on the lawn as Montag shot one continuous pulse of liquid fire on him.

- ... Granger looked at him and nodded him on. Montag went ahead. ${ }^{48}$

\section{Personal Transformation}

- His mind would well over at last and he would not be Montag any more, this the old man told him, assured him, promised him. He would be Montag plus Faber, fire plus water, and then, one day, after everything had mixed and simmered and worked away in silence, there would be neither fire not water, but wine. Out of two separate and opposite things, a third. ${ }^{49}$

\section{Opposition}

The definition and role of the Opposition (the novel's antagonist Beatty, as well as the Mechanical Hound, which is the nonhuman opposition, a sort of "monster" opposing the quest), as a principal foil to the Subject of the novel is, I believe, straightforward.

- "Stick with the fireman, Montag. All else is dreary chaos!"

- "Don't listen...[Beatty's] trying to confuse. He's slippery. Watch out!"

- I've got you going, have I Montag?... Shall I talk some more? I like your look of panic." 50

\section{Fahrenheit 451 Transformational Quest Plot Schemata, base on Vladimir Prop}

${ }^{47}$ Bradbury, ibid, pp. 3, 4 .

${ }^{48}$ Bradbury, ibid, pp. 119, 164.

${ }^{49}$ Bradbury, ibid, p. 103.

${ }^{50}$ Bradbury, ibid, pp. 106, 106, 107. 
I will now amend the above description, as part of the "building block" approach to narrative analysis referred to in the introduction of this paper. I propose the following Transformational Quest Plot Schemata, based on Vladimir Propp's description of the "functional" attributes in Russian fairy tales, which incorporates the main characters, actors, actants and other elements from the A.J. Greimas diagram into a more comprehensive temporal disposition. Our purpose is to refine our examination of plot and the transformational quest in Bradbury's novel, and to expose and clarify patterns and relationships among the varied themes and elements within the narrative flow. The schemata is limited to the action of Bradbury's narrative and not intended to be "universally" applicable. Again I ask the reader's consent in this exercise, and I hope the combination of Greimas's and Propp's work is valid and revealing. Refer to the Transformational Quest Plot Schemata, below, during the following description and analysis of the three phases of the Transformational Quest in Fahrenheit 451.

Montag's quest is instigated soon after he meets Clarisse, the Change Agent in the quest. Clarisse prompts Montag's cognitive and emotional crisis, causing him to question his most closely held values about life, motivation and roles. From this springboard, Montag begins the Initial Stage of his quest, which includes enhanced understanding of the Object he seeks, his contact with the Principal Helper on his quest, and confrontation with the Opposition. Montag's first confrontation with Beatty in Montag's home is interesting, in that Beatty describes for Montag the origins and contours of the social decay that Montag will seek to redress. It is only then that Montag can begin to fully understand the Object of his quest, and his own motivations. Beatty is something of a dark opposite to Montag, for although he (Beatty) fully understands the background of the current social situation, and its gravity and meaning, he has decided to permanently side with the Opposition. Montag's and Beatty's confrontation continues, leading up to their showdown in the front yard of a house they have been dispatched to burn. Here Montag attacks and kills Beatty, and is initially transformed into the Hero of the quest, At this point, however, Montag's transformation is only partial, and it will gradually build in complexity and density, before he is transformed into a full-fledged hero with all of the attendant responsibilities.

The Intermediate Stage of Montag's transformational quest begins with his pursuit by the Opposition, which is now marshalling its forces against him. He seeks the aid of his Principal Helper, Faber, who assists him in evading the Opposition and travelling into a wilderness, where his most important collaborators, the Instrumental Helpers, will be found, and where he will continue his quest and personal transformation. In the wilderness/exile, Montag searches his memory for clues to his role and destiny (such retrieval of memory will play a key role in his final transformation as well), and is confronted by imagined demons and Opposition. Such "questioning" has of course been going on with Montag throughout the novel, but in his travels down the river, he first has a chance to truly plumb his feelings in order to understand his evolving role.

The Final Stage of Montag's transformational quest begins with his contact with his Instrumental Helpers in the forest. The Instrumental Helpers bolster Montag's knowledge of his personal transformation and his quest to re-supply society with intellectual freedom, intellectuality and literacy. After consultations with them, the narrative races ahead, and quite independently of plans Montag and his helpers have made, society (the Subject's Origins) is transformed (that is, destroyed) in a nuclear conflagration. During this final transformation of Origins, Montag is himself fully transformed - first on a personal level, when he succeeds in remembering where he originally met his wife, his failure earlier in the novel which connoted his spiritual and personal emptiness - and then into a full-fledged Hero, when he is designated as the formal leader of the social vanguard that will deliver the quest's Object to the Receiver (society, culture, humanity). This social restoration will, of course, constitute the true transformation of society, the highest aim of the quest in Bradbury's narrative. At the end of the novel, the group of survivors begins their "long morning's walk until noon" in order to "reach the city," leaving no doubt of Bradbury's purpose, and also fitting in with classic quest structure, with the Subject returning to his Origins to deliver the Object.

\section{Fahrenheit 451: Transformational Quest Plot Schemata}

\section{Based on Vladimir Propp functional description of narrative, and A.J. Greimas opposition matrix plot description} (author's additions in bold)

1. Subject is first seen (as Villain, opposing Sender/Provider and undermining Object)

2. Subject's cognitive/moral crisis and initial transformation is instigated by Change Agent

\section{Initial stage of Quest/Subject Transformation}

3. Subject questions accepted truths 
4. Opposition attempts to sway Subject (with logic or deceit)

5. Subject confronts accepted truths

6. Principal Helper is sought

7. Opposition confronts Subject

8. Subject repels Opposition-Subject is initially transformed into Hero

\section{Intermediate stage of Quest/Subject Transformation}

9. Subject is pursued by Opposition

10. Principal Helper provides help

11. Subject escapes from Opposition

12. Subject travels into wilderness/exile where he retrieves memory and encounters demons (troubled memory; imagined Opposition)

\section{Final stage of Quest/Subject Transformation}

13. Subject contacts Instrumental Helpers (formerly Opposition, now seen as Helpers); Instrumental Helpers bolster Subject's knowledge of his transformation

14. Origins are transformed

15. Final personal transformation of subject and transformation into Hero

16. Subject returns to origins in order to deliver Object to Receiver(s)

\section{CONCLUSION}

I have probed Ray Bradbury's Fahrenheit 4541 on roughly three tracks in this analysis: 1) The quest Bradbury portrayed in Fahrenheit 451, and the narrative devices and approach he employed to fashion this quest. These facets, I feel, are often best classified and understood structurally, as recognizable patterns and functions, and so I turned to the work of A.J. Greimas and Vladimir Propp in our analysis. 2) The key theme of transformation Bradbury addressed in Fahrenheit 451 on two levels: in his social critique, which was acute in its understanding of decay in American society of its time, and perceptive in its forecast of future technological and social changes; and personal transformation, which saw a product of that repressed culture change from a weak and ignorant follower into a courageous leader. 3) The fruits of Bradbury's storyteller's impulse: his ranging imagination, genre-bending narrative technique, variegated thematic approach, and richly polychromatic writing style.

I hope these approaches have complemented each another, enriching and deepening the meaning, narrative contours and quest structure I have tried to uncover in this paper. Ultimately, the breadth and depth of Bradbury's meaning and narrative scope should not surprise us, for he has always taken on big themes in unusual ways. Yet he always simultaneously focused on a good tale told in the best possible way. It may be this unique combination of the high and low, the majestic and the humble, that has enabled Bradbury to establish his notable position in American literature.

\section{REFERENCES}

Ashley, Bob, The Study of Popular Fiction; A Source Book, Printer Publishers, London, 1989.

Barthes, Roland, Stephen Heath (trans). "Introduction to the Structural Analysis of Narratives," from Image-Music-Text, Hill and Wang, New York City, 1978.

..., Sontag, Susan (ed). A Roland Barthes Reader, Hill and Wang, New York City, (1983).

Bradbury, Ray. Fahrenheit 451, Random House Publishing Group, New York City, 1953.

De Koster, Katie (ed). Readings on Fahrenheit 451, Literary Companion Series, Greenhaven Press, 2000.

Greimas, A.J. Structural Semantics: An Attempt at a Method. trans. Daniele McDowell, Ronald Schleifer, and Alan Velie. Lincoln, Nebraska: University of Nebraska Press, 1983.

... On Meaning. trans. Frank Collins and Paul Perron. Minneapolis: University of Minnesota Press, 1987.

Hawkes, Terrence. Structuralism and Semiotics, Routledge, London, 1997.

Merriam-Webster's Collegiate Dictionary, Tenth Edition, Merriam-Webster, Inc. Springfield, Massachusetts, 1998.

Propp, Vladimir. Morphology of the Folktale. Trans., Laurence Scott. 2nd ed. Austin: U of Texas Press, 1968 